\title{
Implications of Future Water Use Efficiency for Ecohydrological Responses to Climate Change and Spatial Heterogeneity of Atmospheric $\mathrm{CO}_{2}$ in China
}

\author{
Zhen Zhang ${ }^{1,2}$, Hong Jiang ${ }^{2,3, *}$, Jinxun Liu ${ }^{4}$, Juejing Han $^{5}$, Qiuan Zhu ${ }^{6}$, and Xiuying Zhang ${ }^{2}$ \\ ${ }^{1}$ Cold and Arid Regions Environmental and Engineering Research Institute, CAS, Lanzhou, China \\ ${ }^{2}$ International Institute for Earth System Science, Nanjing University, Nanjing, China \\ ${ }^{3}$ State Key Laboratory of Subtropical Forest Science \& Zhejiang Provincial Key Laboratory of Carbon Cycling in Forest \\ Ecosystems and Carbon Sequestration, Zhejiang Agriculture and Forestry University, Hangzhou, China \\ ${ }^{4}$ Stinger Ghaffarian Technologies (SGT, Inc.), Sioux Falls, South Dakota, USA \\ ${ }^{5}$ Suzhou Meteorological Bureau, Suzhou, China \\ ${ }^{6}$ Institute of Environment Sciences, University of Quebec at Montreal, Montreal, Canada
}

Received 20 January 2012, accepted 3 December 2012

\begin{abstract}
As the atmospheric carbon dioxide $\left(\mathrm{CO}_{2}\right)$ increases substantially, the spatial distribution of atmospheric $\mathrm{CO}_{2}$ should be considered when estimating the effects of $\mathrm{CO}_{2}$ on the carbon and water cycle coupling of terrestrial ecosystems. To evaluate this effect on future ecohydrological processes, the spatial-temporal patterns of $\mathrm{CO}_{2}$ were established over $1951-2099$ according to the IPCC emission scenarios SRES A2 and SRES B1. Thereafter, water use efficiency (WUE) was used (i.e., Net Primary Production/Evaportranspiration) as an indicator to quantify the effects of climate change and uneven $\mathrm{CO}_{2}$ fertilization in China. We carried out several simulated experiments to estimate WUE under different future scenarios using a land process model (Integrated Biosphere Simulator, IBIS). Results indicated that the geographical distributions of averaged WUE have considerable differences under a heterogeneous atmospheric $\mathrm{CO}_{2}$ condition. Under the SRES A2 scenario, WUE decreased slightly with a $5 \%$ value in most areas of the southeastern and northwestern China during the 2050s, while decreasing by approximately 15\% in southeastern China during the 2090s. During the period of the 2050s under SRES B1 scenario, the change rate of WUE was similar with that under SRES A2 scenario, but the WUE has a more moderate decreasing trend than that under the SRES A2 scenario. In all, the ecosystems in median and low latitude areas had a weakened effect on resisting extreme climate event such as drought. Conversely, the vegetation in a boreal forest had an enhanced buffering capability to tolerate drought events.
\end{abstract}

Key words: Water use efficiency (WUE), Atmospheric $\mathrm{CO}_{2}$, IPCC scenario, IBIS, China

Citation: Zhang, Z., H. Jiang, J. Liu, J. Han, Q. Zhu, and X. Zhang, 2013: Implications of future water use efficiency for ecohydrological responses to climate change and spatial heterogeneity of atmospheric $\mathrm{CO}_{2}$ in China. Terr. Atmos. Ocean. Sci., 24, 451-465, doi: 10.3319/TAO.2012.12.03.01(Hy)

\section{INTRODUCTION}

Terrestrial ecosystems are of particular importance within the global carbon and water cycles because of the large carbon sequestrated in plants and the large hydrological effects by evaportranspiration (Alo et al. 2008a; Bell et al. 2010). Changes in the carbon and water cycle couplings of terrestrial ecosystems could have significant responses to environmental factors such as temperature, precipitation, and atmospheric $\mathrm{CO}_{2}$ (Arneth et al. 2010). Atmospheric $\mathrm{CO}_{2}$ concentrations have increased from preindustrial lev-

\footnotetext{
* Corresponding author

E-mail: jianghong_china@hotmail.com
}

els of $280 \mathrm{ppm}$ to the present level of around $390 \mathrm{ppm}$ in 2009 (Friedlingstein et al. 2010). It is likely that global climate changes will continue to influence the Northern Hemisphere's precipitation distributions with an increase in frequency and intensity of extreme climate events (IPCC 2001 , 2007). Impacts of future climate change on the ecohydrological processes are topics of serious concern in global change research.

Water Use Efficiency (WUE), as a key indicator for the carbon and water cycle coupling of terrestrial ecosystems, is used to describe the trade-off between water loss and carbon gain in the process of plant photosynthesis 
(LeHouerou 1984; Baldocchi 1994) and perhaps reflect responses of plants to environmental stress on ecosystem processes (Huxman et al. 2004). Based on different scales and approaches, WUE has different meanings due to the different complexity of physical and physiological processes involved (Law et al. 2002). It has been widely observed that WUE is expected to increase with rising $\mathrm{CO}_{2}$ concentrations, albeit of uncertain scale (Deng et al. 2006; Kuglitsch et al. 2008; Yu et al. 2008; Erbs et al. 2009; Peñuelas et al. 2010; Zheng et al. 2010). The increased $\mathrm{CO}_{2}$ concentration is important for future adaptation of WUE because it may directly stimulate plant photosynthesis and indirectly reduce plant water consumption through regulating stomatal conductance (Baldocchi 1997).

Since the 1990s, the spatial-temporal heterogeneity of atmospheric $\mathrm{CO}_{2}$ concentration has been detected from ground-based $\mathrm{CO}_{2}$ measurement networks such as Global Atmospheric Watch (GAW) (Ciais et al. 2000; Peters et al. 2007). However, due to the sparseness of observation stations, the spatial variations of $\mathrm{CO}_{2}$ is used to be considered small and not lead to significant effect on global ecosystems (Chapin et al. 2002). Beginning in the early 2000s, $\mathrm{CO}_{2}$ monitoring with remote sensing technology was developed at large scale. The Scanning Imaging Absorption Spectrometer for Atmospheric Cartography (SCIAMACHY) of ENVISAT (Buchwitz et al. 2007) and the Greenhouse Gases Observing Satellite (GOSAT) of IBUKI (Buchwitz et al. 2007; Yokota et al. 2009), observed approximately \pm 20 ppm variations in different regions (Zhang et al. 2013a). This requires carbon scientists to reconsider WUE responses to the effect of heterogeneous atmospheric $\mathrm{CO}_{2}$ concentration at a regional and global scale.

The effect of future climate change and rising atmospheric $\mathrm{CO}_{2}$ on ecohydrological processes has been studied based on general circulation models for a given future greenhouse gas emission scenarios (Cramer et al. 2001). Recent studies showed that modeled runoff decreased globally with an increase in temperature due to increased evaportranspiration. However, an increase in precipitation in future scenarios in mid-latitude regions results in increased runoff due to oversaturation of soil moisture. As the atmospheric $\mathrm{CO}_{2}$ reaches to $550 \mathrm{ppm}$ in the $2050 \mathrm{~s}$, a decrease of transpiration from plants due to a more efficient stomatal opening might occur (Farquhar et al. 1982). It is essential to predict how WUE acting within terrestrial ecosystems would respond to changes in environmental and increasing atmospheric $\mathrm{CO}_{2}$ in the future (Xu et al. 2004).

The process-based terrestrial ecosystem models are important tools to study WUE under atmospheric $\mathrm{CO}_{2}$ concentration dynamics and predict future responses of WUE with regard to climate change. Studies with a large-scale ecosystem model which simulate rising $\mathrm{CO}_{2}$ levels and future climate change effects on ecohydrological processes have not yet considered the spatial heterogeneity of the $\mathrm{CO}_{2}$ effect in simulated experiments (Yu et al. 2004; Bell et al. 2010; Tian et al. 2010; Zhu et al. 2011). This study aims to use the Integrated Biosphere Simulator (IBIS) to generate WUE under different scenarios made up of different climate change and $\mathrm{CO}_{2}$ concentration conditions. The major objectives are to (1) demonstrate the sensitivity of WUE in China under heterogeneous $\mathrm{CO}_{2}$ concentrations; (2) evaluate the responses of WUE on terrestrial ecosystems in China to future climate change (e.g., warming and changing precipitation pattern) and heterogeneous $\mathrm{CO}_{2}$ concentrations; (3) explore the potential relationship between spatial patterns of WUE in future scenarios and environmental change factors especially the spatial-temporal pattern of $\mathrm{CO}_{2}$ concentrations.

\section{MATERIALS AND METHODS}

\subsection{Study Area and Water Use Efficiency Calculation}

In this study, climate zones, categorized into 11 major regions by using basic meteorological principles (temperature and moisture) were used to analyze the different responses of WUE under different climates and geographical conditions in China (Fig. 1).

WUE had different definitions depending on the spatial-temporal scales and research communities (Richards et al. 2002; Steduto et al. 2005). At leaf level the water consumption was considered to be transpiration $(\mathrm{T})$, while the water consumption was using evaportranspiration (ET) at the ecosystem level. Net primary production (NPP) could reflect annual net carbon fixation in ecosystems and represent as the difference between carbon assimilation and plant respiration. NPP is primarily determined by the photosynthesis rate, plant maintenance respiration, and growth respiration. In this study, WUE at ecosystem level was calculated as the ratio of NPP to ET expressed as WUE $=\mathrm{NPP} / \mathrm{ET}$ (Law et al. 2002; Hu et al. 2008).

\subsection{IBIS Model Description}

The IBIS model is designed to be an integrated, physically consistent modeling framework which includes land surface processes, canopy physiology, vegetation phenology long-term vegetation dynamics, and carbon cycling. Detailed IBIS model descriptions are available elsewhere (Foley et al. 1996 and Kucharik et al. 2000). However, this original model does not contain a complete nitrogen $(\mathrm{N})$ cycle. A modified version of IBIS which is applied in this study was developed to overcome this limitation (Liu et al. 2005).

The hydrological module is constructed based upon a land-surface-transfer scheme (LSX) (Thompson et al. 1995a, b). This module applied two canopy layers, three snow layers, and six soil layers to construct a pseudo-physical land surface. The total amount of evaportranspiration from the land surface is calculated as the sum of three water vapor 


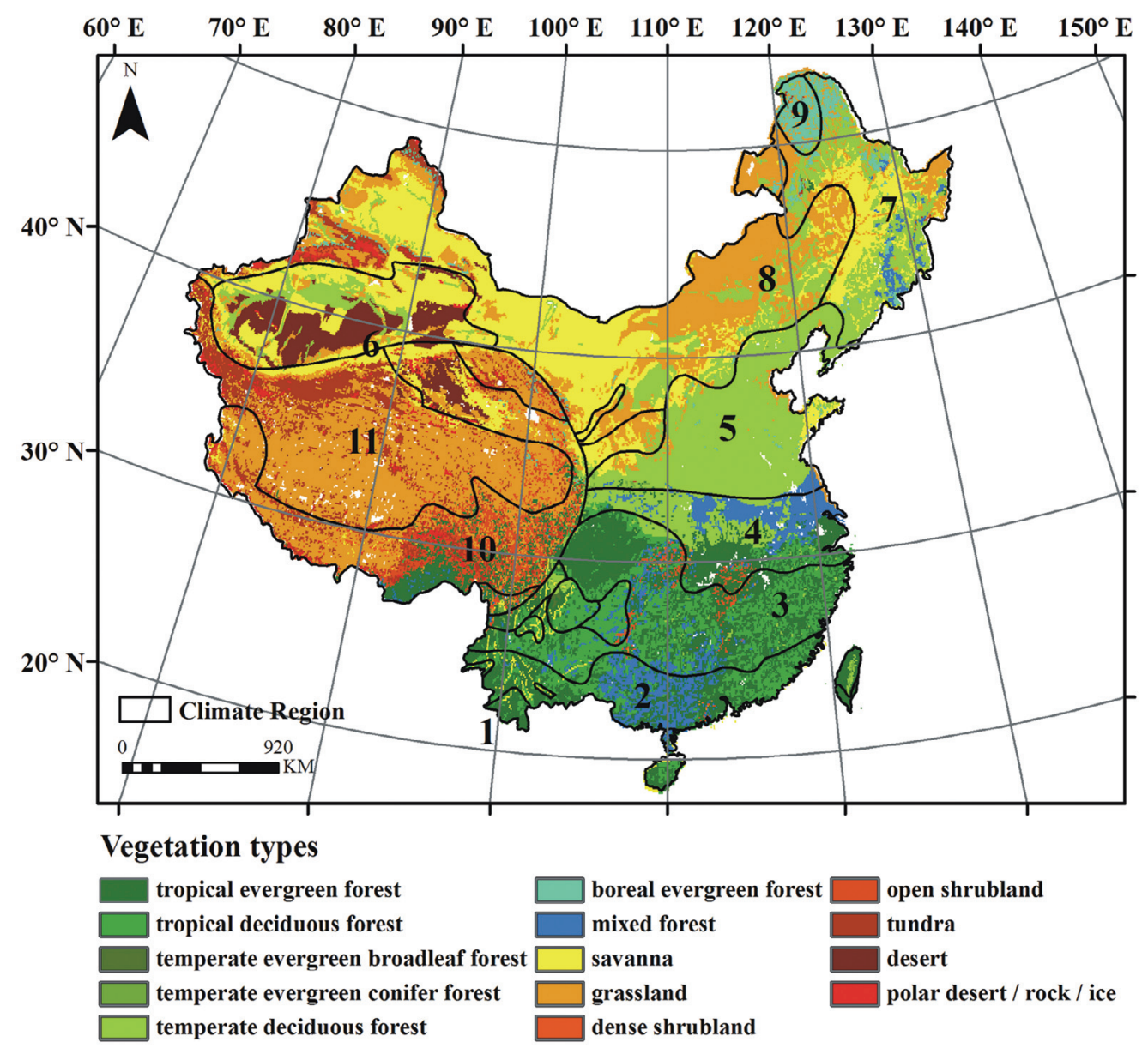

Fig. 1. Vegetation type map and the geographical delineation of climate zones in China (excluding the Southern China sea region): (1) Marginal Tropical (MT); (2) Southern Subtropical (SS); (3) Middle Subtropical (MS); (4) Northern Subtropical (NS); (5) Wet/Warm Temperate (W/WT); (6) Dry/Warm Temperate (D/WT); (7) Wet/Middle Temperate (W/MT); (8) Dry/Middle Temperate (D/MT); (9) Cold Temperate (CT); (10) Plateau Temperate (PT); and (11) Plateau Frigid (PF).

fluxes: canopy transpiration $\left(\mathrm{E}_{\mathrm{u}}, \mathrm{E}_{1}\right)$, evaporation of water intercepted by vegetation canopies $\left(\mathrm{E}_{\mathrm{s}}\right)$, and evaporation from the soil surface $\left(\mathrm{E}_{\mathrm{g}}\right)$. Evaporation rates are calculated using standard mass transfer equations relating the temperature of the surface, vapor pressure deficit, and conductance (Campbell and Norman 1998). The calculation equations were described as follows:

$E_{u}=\rho s_{u}\left[f_{u}^{\text {wet }}+\frac{\left(1-f_{u}^{\text {wet }}\right) f_{u}^{\text {sto }}}{1+r_{u} s_{u}}\right]\left[q_{\text {sat }}\left(T_{u}\right)-q_{12}\right]$

$E_{s}=\rho s_{s} f_{s}^{\text {wet }}\left[q_{\text {sat }}\left(T_{s}\right)-q_{12}\right]$

$E_{1}=\rho s_{1}\left[f_{1}^{\text {wet }}+\frac{\left(1-f_{1}^{\text {wet }}\right) f_{1}^{\text {sto }}}{1+r_{1} s_{1}}\left(\frac{L^{2} I_{1}}{L_{A I}+S A I_{1}}\right)\right]\left[q_{\text {sat }}\left(T_{1}\right)-q_{34}\right]$

where the subscripts ' $\mathrm{u}$ ', 's', and ' $\mathrm{l}$ ' denote upper-story leaves, upper-story stems, lower-story vegetation, $\mathrm{E}_{\mathrm{u}}, \mathrm{E}_{\mathrm{s}}$, and $E_{1}$ were fluxes of water vapor from a unit leaf/stem surface area including evaporation of intercepted water, dew formation and transpiration, $\mathrm{LAI}_{1}$ and $\mathrm{LAI}_{\mathrm{u}}$ represented the upper and lower canopy index respectively. $\mathrm{f}_{\mathrm{u}}^{\text {wet }}, \mathrm{f}_{\mathrm{s}}^{\mathrm{wet}}, \mathrm{f}_{1}^{\mathrm{wet}}$ and are the fractions of leaf and stem areas wetted by intercepted liquid or snow. $r_{u}$ and $r_{1}$ are the stomatal resistance per unit leaf area for upper and lower stories $\left(\mathrm{s} \mathrm{m}^{-1}\right)$ respectively. $\mathrm{f}_{u}^{\text {sto }}$ and $\mathrm{f}_{1}^{\text {sto }}$ are 0.5 or 1 for leaves with stomata on one or both sides respectively, $\rho$ is the density of near-surface air $\left(\mathrm{kg} \mathrm{m}^{-3}\right) ; \mathrm{S}_{\mathrm{u}}, \mathrm{S}_{\mathrm{s}}$, and $\mathrm{S}_{1}$ are heat/vapor transfer coefficients between vegetation and canopy air $\left(\mathrm{m} \mathrm{s}^{-1}\right) \cdot \mathrm{q}_{\mathrm{sat}}(\mathrm{T})$ is the saturation specific humidity versus temperature at ambient pressure $\left(\mathrm{kg} \mathrm{kg}^{-1}\right) ; \mathrm{q}_{12}$ and $\mathrm{q}_{34}$ are canopy air specific humidity for upper and lower stories, respectively $\left(\mathrm{kg} \mathrm{kg}^{-1}\right)$.

To account for evaporation from intercepted rain, the model describes the interception and cascade of precipitation (including rain and snow) through the canopies (Foley et al. 1996; Kucharik et al. 2000). To generate daily weather rainfall, the IBIS model uses a series of weather generator approaches which generate random combinations 
of weather conditions based upon monthly climatological conditions (Richardson 1981; Richardson et al. 1984; Geng et al. 1986). The wet day calculation in this approach is from the averaged climatical data as a constant value. Therefore, the intensity and frequency of daily and hourly precipitation will increase when monthly precipitation increases.

The soil evaporation algorithm uses the beta method:

$E_{g}=\rho C_{E} U_{a} \beta\left(q_{s}-q_{a}\right)$

where $E_{g}$ was the evaporation from bare soil, $\rho$ was the air density, $C_{E}$ was the drag coefficient for evaporation, $U_{a}$ was the wind speed at $Z_{a}$ (the atmospheric reference level), $\beta$ was the moisture availability parameter, $\mathrm{q}_{\mathrm{a}}$ was the specific humidity at $Z_{a}, q_{s}$ was the saturated specific humidity which is given by the surface temperature.

The canopy physiology module included photosynthesis and stomatal conductance which were based on a canopy photosynthesis mechanism model and a semi-mechanistic model of stomatal conductance (Farquhar et al. 1980, 1982). The NPP calculation was different from each of the plant functional types. The model version we used does not include agriculture or the effects of human activities on land use change. IBIS has been extensively validated in comparison to observations of terrestrial biogeochemistry and biogeography (Cramer et al. 2001; Vano et al. 2006; Twine et al. 2008; Zhu et al. 2010, 2011).

\subsection{Driving Climate Projections, Spatial Heterogeneity of Atmospheric $\mathrm{CO}_{2}$ Concentration}

IBIS requires monthly climate data (temperature, precipitation, relative humidity, cloud cover, wind speed, and wet days), atmospheric $\mathrm{CO}_{2}$ concentration, $\mathrm{N}$ deposition and soil texture as input data. Fundamental data for simulation were collected from Zhu et al. 2010. In addition, vegetation cover fractions, initial biomass carbon, initial soil carbon, soil texture, topography, and monthly climate data were interpolated to ensure consistency. Vegetation cover fractions were calculated from the 300-m resolution GLC map. Initial biomass was derived from Olson's World Ecosystem database (Gibbs et al. 2006). Initial soil information was obtained from the IGBP global database (Task 2000). Atmospheric nitrogen deposition data were acquired from the Earth Science Information Partner (ESIP) database of the EOS-WEBSTER, which covers the early 1990s.

In order to quantify the climate projection for the period 1951 - 2100, we use two time periods climate data which are from 1951 - 2006 and 2007 - 2100. The earlier climate data originated from a ground station observation covering the period 1950 - 2006. The future climate projection for the $21^{\text {st }}$ century was obtained from GCM simulations performed for IPCC-AR4, using CGCM3 dataset which was from the Canadian Centre for Climate Modeling and Analysis (CCCma) (http://www.ec.gc.ca/ccmac-cccma). To match the simulation resolution in China, the ANUSPLIN software was applied to make the interpolation (Hutchinson 1984). As a downscaling technology, the ANUSPLIN software is based upon the thin plate spline function theory, highlighting with its interpolation accuracy for meteorological dataset (Hutchinson et al. 1994). Two future scenarios were applied as the assumptions of different situations: in 'SRES A2' scenario, atmospheric $\mathrm{CO}_{2}$ concentrations reach $850 \mathrm{ppm}$, while $\mathrm{CO}_{2}$ concentrations reach $560 \mathrm{ppm}$ in SRES B1 scenario (Fig. 2). Hence, the IBIS simulations driven by the two climate projections should have distinct atmospheric $\mathrm{CO}_{2}$ increase and ecosystem response.

The spatial-temporal heterogeneity of atmospheric $\mathrm{CO}_{2}$ concentration has been detected from a ground-based $\mathrm{CO}_{2}$ measurement network named the Global Atmosphere Watch (GAW) (Zhang et al. 2008). Satellite observations also became a reliable technology for representing the spatial variation of atmospheric $\mathrm{CO}_{2}$ (Buchwitz et al. 2007). We used a linear regression model and a sine wave model based on GAW and SCIAMACHY data to establish the spatial-temporal pattern of atmospheric $\mathrm{CO}_{2}$ concentration over 1951 - 2099 (Zhang et al. 2013b). Figure 3 shows the spatial heterogeneity and seasonal amplitude of atmospheric $\mathrm{CO}_{2}$ concentrations among climate zones in China. The seasonal amplitude in CT zone was the highest with about $14 \mathrm{ppm}$ (Fig. 3a). The high $\mathrm{CO}_{2}$ concentration regions were primarily located in southeast and central China (Fig. 3b). This indicated that the spatial and temporal variations of $\mathrm{CO}_{2}$ were more complicated in China.

\subsection{Experiment Setup and Validation}

IBIS simulations were performed using six experiments: (1) A2 with heterogeneous $\mathrm{CO}_{2}$ increases, (2) $\mathrm{A} 2$ with uniform $\mathrm{CO}_{2}$ increases, (3) $\mathrm{B} 1$ with heterogeneous $\mathrm{CO}_{2}$ increases, (4) $\mathrm{B} 1$ with uniform $\mathrm{CO}_{2}$ increases, (5) $\mathrm{A} 2$ with no $\mathrm{CO}_{2}$ increases, and (6) $\mathrm{B} 1$ with no $\mathrm{CO}_{2}$ increases. For the period 1950 - 2006, we used the trend of $\mathrm{CO}_{2}$ increase from ESRL. For 2007 - 2099, annual values for SRES A2 and SRES B1 scenarios, calculated by the ISAM model, were used to generate future $\mathrm{CO}_{2}$ increase trends (IPCC 2001).

Simulations (1) and (3), with $\mathrm{CO}_{2}$ enrichment and spatial variability, denoted as $\mathrm{CO}_{2}-\mathrm{E}$, will be compared with the simulations of $\mathrm{CO}_{2}$ enrichment but with no spatial variability (2) and (4), denoted as $\mathrm{CO}_{2}-\mathrm{B}$ in order to quantify the potential impacts of spatially heterogenic distribution of $\mathrm{CO}_{2}$ on $\mathrm{C}$ sequestration. Simulations (5) and (6), denoted as $\mathrm{CO}_{2}-\mathrm{N}$, are used primarily to quantify the effects of $\mathrm{CO}_{2}$ increase on $\mathrm{C}$ sequestration with simulations (2) and (4). By comparing the six model simulations, the effects of $\mathrm{CO}_{2}$ fertilization and heterogeneous $\mathrm{CO}_{2}$ enrichment can be quantified (Table 1). 
The IBIS simulation in China was performed at 0.085 degrees $(\sim 10-\mathrm{km})$ resolution. The spin-up period was from simulated 1901 to 1950 (using 1951 - 2000 average climate condition) to obtain vegetation and soil carbon pools in an approximate steady-state at the beginning of the subsequent climate change experiment. Only the transient period from 1951 - 2099 was analyzed.

The IBIS model has been evaluated over a large number of studies and validated with independent field observations, inventory, and remote sensing data (Zhu et al. 2010). The Net Primary Production (NPP) and biomass data were previously validated against forestry inventory data; Gross Primary Production (GPP) was validated with carbon flux site data. The validation and comparison showed reasonable agreement (Zhu et al. 2010). The hydrological processes of IBIS were validated with observed runoff (up to 39 years observed data for 85 hydrological gauges) and soil moisture data (up to 40 soil moisture stations' monthly observed data from 1981 to 1999) (Zhu et al. 2010).

\section{RESULTS}

\subsection{Present-Day Water Use Efficiency}

WUE of the plants in the terrestrial ecosystems of China ranged from $0.47 \mathrm{~g} \mathrm{C} \mathrm{kg}^{-1} \mathrm{H}_{2} \mathrm{O}$ in tundra to $0.81 \mathrm{~g} \mathrm{C} \mathrm{kg}^{-1}$ $\mathrm{H}_{2} \mathrm{O}$ in a temperate evergreen broadleaf forest with an average of $0.49 \mathrm{~g} \mathrm{C} \mathrm{kg}^{-1} \mathrm{H}_{2} \mathrm{O}$ from 1981 to 2000 (see Table 2). This implied that about $0.49 \mathrm{~g} \mathrm{C}$ had been fixed in the plants as the net primary productivity using $1 \mathrm{~kg}$ water. The mean annual modeled WUE in the present-day were within a reasonable range of different studies for China. Hu et al. (2008) reported that the WUE values of grassland ranged from 0.41 to $1.26 \mathrm{~g} \mathrm{C} \mathrm{kg}^{-1} \mathrm{H}_{2} \mathrm{O}$ based on flux data. Law et al. (2002) applied eddy covariance technology to calculate WUE in tundra with an average of $0.41 \mathrm{~g} \mathrm{C} \mathrm{kg}^{-1} \mathrm{H}_{2} \mathrm{O}$ which was similar to our estimated result. The modeled WUE for different forest types in this study was slightly lower than that estimated by Kuglitsch et al. (2008) and Yu et al. (2008) and roughly equals to the estimation by Tian et al. (2010) in the

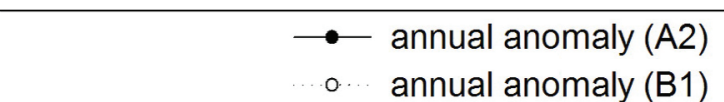

(a)

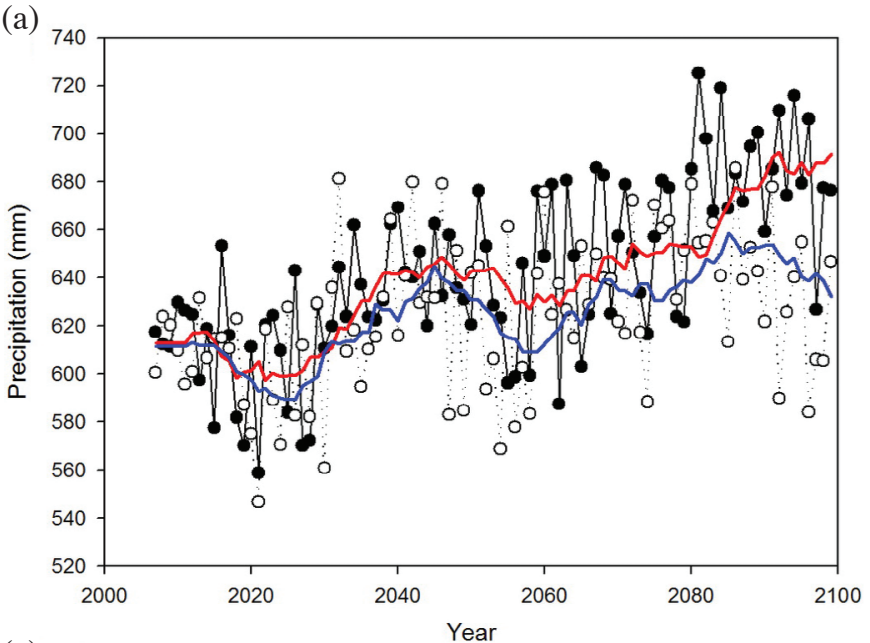

(c)

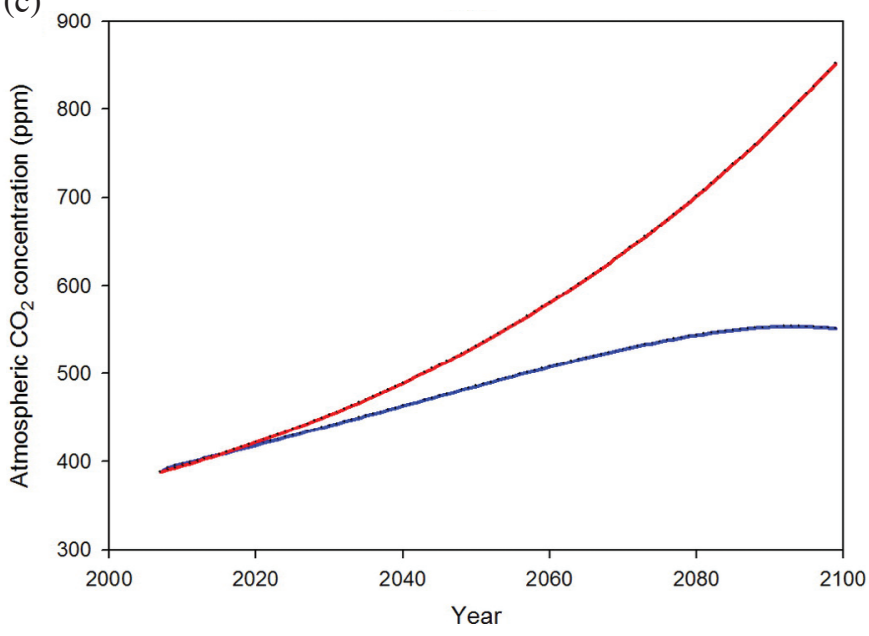

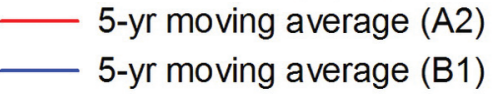

(b)

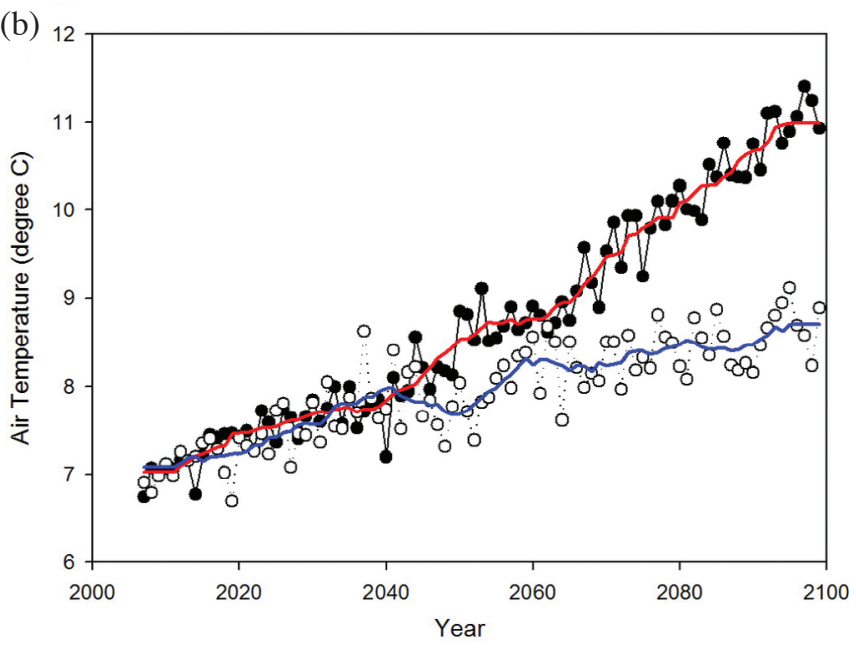

Fig. 2. Magnitude of changes in major climate change factors and elevated atmospheric $\mathrm{CO}_{2}$ in China under future scenarios. (a) Annual precipitation ( $\mathrm{mm}$ ) from 2006 to 2099; (b) mean annual temperature (degree C) from 2006 to 2099 ; (c) atmospheric $\mathrm{CO}_{2}$ concentration from 2006 to 2099 . 

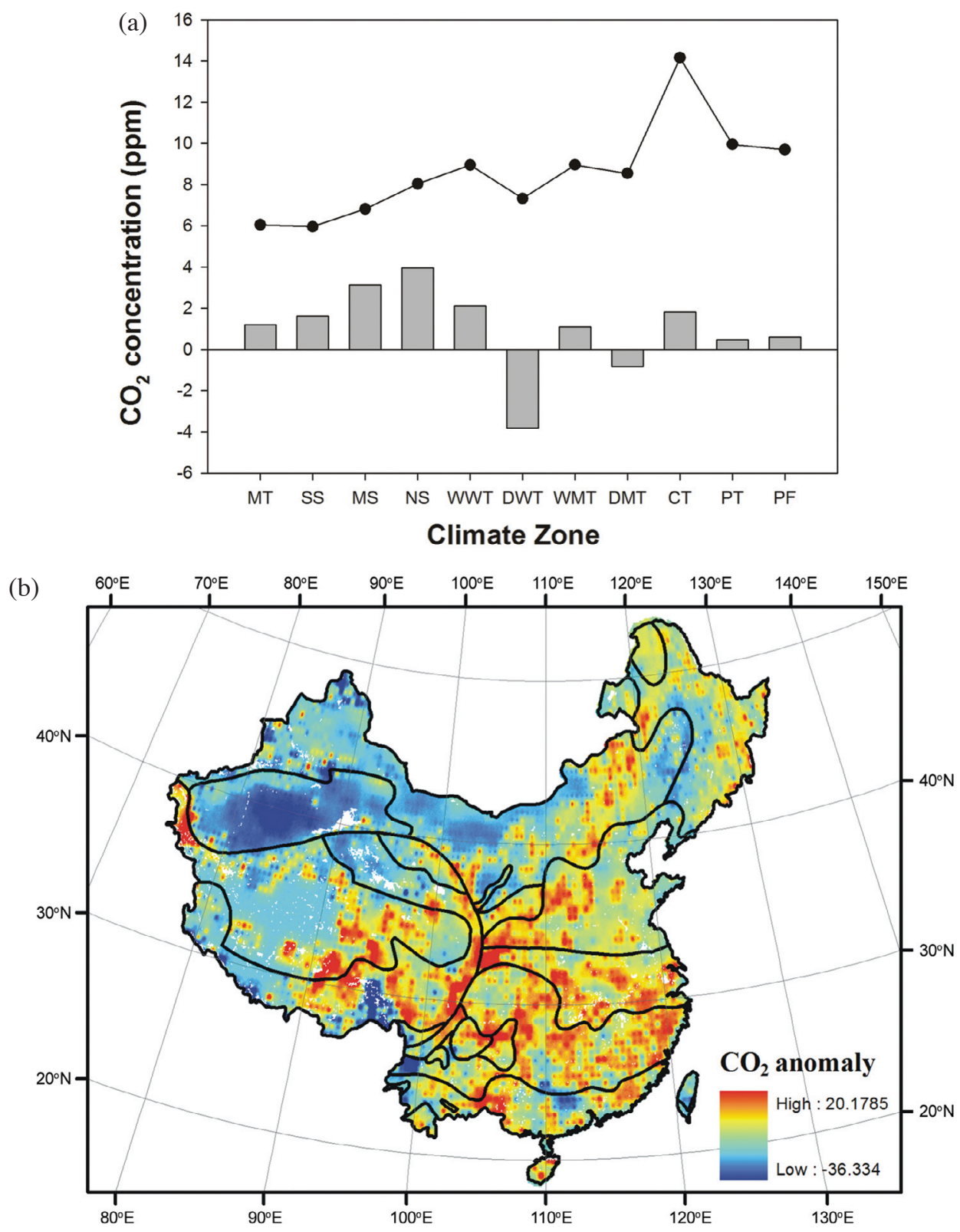

Fig. 3. Modeled spatial anomaly of surface $\mathrm{CO}_{2}$ concentrations in China using satellite data and ground-based observation. (a) An anomaly of the mean $\mathrm{CO}_{2}$ concentration across different climate zones in China. The dotted line represents the inter-annual magnitude of the mean $\mathrm{CO}_{2}$ concentration in each climate zone. The vertical bars show the mean deviation of $\mathrm{CO}_{2}$ differences with respect to the annual global average level. (b) Spatial pattern of the monthly $\mathrm{CO}_{2}$ concentration anomaly in China.

Table 1. Conditions of each simulation experiment.

\begin{tabular}{cccccc}
\hline No. & Scenarios & Climate data & $\mathbf{C O}_{2}$ concentration (2050) & $\mathbf{C O}_{2}$ concentration (2099) & $\mathbf{C O}_{2}$ increase type \\
\hline 1 & $\mathrm{~A} 2 \& \mathrm{CO}_{2}-\mathrm{E}$ & SRES A2 (CGCM3) & 531.2 (ISAMS) & 857.1 (ISAMS) & Spatial - variations, monthly \\
2 & $\mathrm{~A} 2 \& \mathrm{CO}_{2}-\mathrm{B}$ & SRES A2 (CGCM3) & 532 (ISAMS) & 856 (ISAMS) & Non Spatial - variations, yearly \\
3 & $\mathrm{~B} 1 \& \mathrm{CO}_{2}-\mathrm{E}$ & SRES B1 (CGCM3) & 485.6 (ISAMS) & 550.7 (ISAMS) & Spatial - variations, monthly \\
4 & $\mathrm{~B} 1 \& \mathrm{CO}_{2}-\mathrm{B}$ & SRES B1 (CGCM3) & 488 (ISAMS) & 549 (ISAMS) & Non Spatial - variations, yearly \\
5 & $\mathrm{~A} 2 \& \mathrm{CO}_{2}-\mathrm{N}$ & SRES A2 (CGCM3) & $305 \mathrm{ppm}(1901$ level) & $305 \mathrm{ppm}$ & No increase \\
6 & $\mathrm{~B} 1 \& \mathrm{CO}_{2}-\mathrm{N}$ & SRES B1 (CGCM3) & $305 \mathrm{ppm}(1901$ level) & $305 \mathrm{ppm}$ & No increase
\end{tabular}


Table 2. List of simulated mean WUE in IBIS from 1981 to 2000.

\begin{tabular}{lc}
\hline Vegetation type & $\begin{array}{c}\text { Mean WUE } \\
\left(\mathbf{g ~ C ~ k g ~}^{-1} \mathbf{H}_{\mathbf{2}} \mathbf{O}\right)\end{array}$ \\
\hline tropical evergreen forest/woodland & $0.88 \pm 0.17$ \\
tropical deciduous forest/woodland & $0.83 \pm 0.16$ \\
temperate evergreen broadleaf forest/woodland & $0.80 \pm 0.14$ \\
temperate evergreen conifer forest/woodland & $0.81 \pm 0.12$ \\
boreal evergreen forest/woodland & $0.56 \pm 0.10$ \\
savanna & $0.66 \pm 0.10$ \\
grassland/steppe & $0.59 \pm 0.11$ \\
dense shrubland & $0.60 \pm 0.12$ \\
open shrubland & $0.09 \pm 0.10$ \\
tundra & $0.47 \pm 0.12$ \\
\hline Overall average & $\mathbf{0 . 4 9} \pm \mathbf{0 . 2 6}$ \\
\hline
\end{tabular}

southern United States. Note that these studies (except Tian et al. 2010) which measure WUE by eddy flux technology is using a different definition of WUE: WUE $=$ GPP/ET. This indicates that the estimated WUE in our study is smaller than that in GPP/ET definition. In addition, the simulated WUE has a different spatial representation $\left(10 \times 10 \mathrm{~km}^{2}\right)$ from flux observations which represent ecosystem level $\left(1 \times 1 \mathrm{~km}^{2}\right)$ results with highly plant coverage.

Compared to the summarized results from different studies, the mean value in China should be considered to be a good representative of WUE at the ecosystem level. The averaged WUE of the terrestrial ecosystems followed an order: Tropical Evergreen Forest $>$ Tropical Deciduous Forest $>$ Warm Temperate Forest $>$ Temperate Forest $>$ Grassland $>$ Shrubland $>$ Tundra (Table 2). These differences between different ecosystems suggested diverse water use abilities and ecohydrological processes involved across terrestrial ecosystems. Even though the processes of water loss and carbon gain are very complicated at the ecosystem level (Yu et al. 2008). Meanwhile, the overestimated ET should be considered in a semi-arid ecosystem such as open shrubland, tundra and desert which was covered by a larger bare area than the other ecosystems. It might thus cause an underestimated WUE in these regions.

\subsection{Temporal and Spatial Variability of Water Use Ef- ficiency}

The temporal averaged annual WUE at the continental scale did vary quite a bit over the entire future period (Fig. 4). WUE was relatively stable before the 2020s and then increased after that with substantial inter-annual fluctuation, but a decreasing trend thereafter. The decreasing trend be-

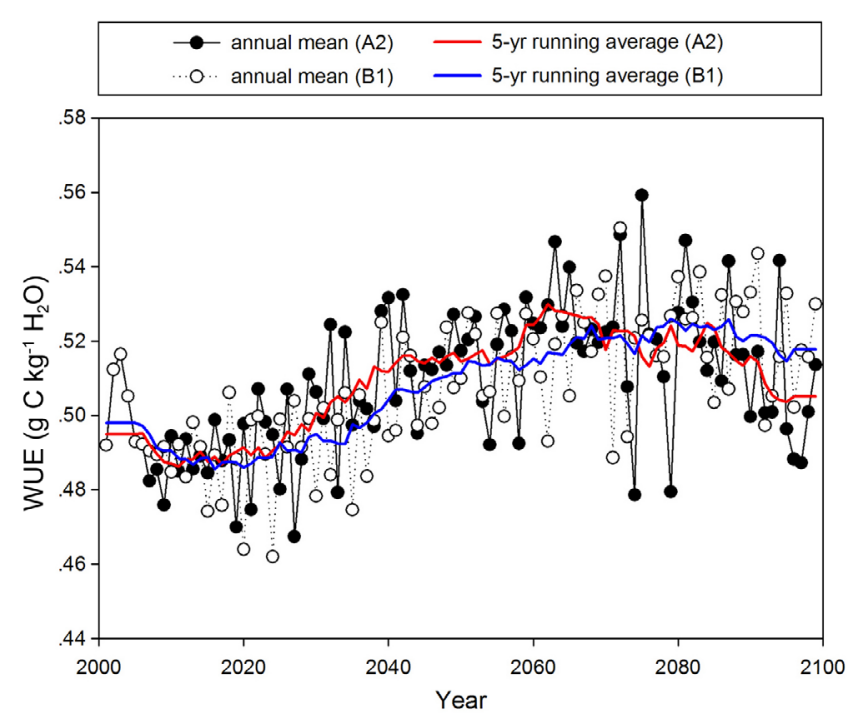

Fig. 4. Annual WUE across the terrestrial ecosystems of China from 2001 to 2099.

fore the 2020s in both scenarios was perhaps attributed to declining precipitation which leads to a decline in ecosystem productivity. The increases in the $\mathrm{A} 2$ and $\mathrm{B} 1$ scenarios between the 2020s and 2060s depend in part on the rising atmospheric $\mathrm{CO}_{2}$ which would enhance photosynthesis and decrease stomatal conductance in plants. The variations of WUE between A2 and B1 scenarios corresponded with plant responses to elevated $\mathrm{CO}_{2}$ wherein the sensitivity of enhanced production would be dampened since the $\mathrm{CO}_{2}$ concentration exceeded a constant level (e.g., $550 \mathrm{ppm}$ ) (Farquhar et al. 1982). Generally, the annual WUE slightly increased (overall) in $21^{\text {st }}$ century under both future projection scenarios but the value was negligible.

Although the overall values of WUE did not change much during the $21^{\text {st }}$ century, a considerable spatial variability was found in China. The anomaly was calculated as a change rate from a multiyear mean between present level and the middle and the end of the century (from 2050 to 2059 and from 2090 to 2099) to evaluate the spatial patterns of changing WUE under different future IPCC scenarios (Fig. 5). The highest positive change rate was generally found in the Tibet Plateau which is predominately covered with grassland and tundra. The lowest change rate was found in southeastern China as well as part of the northeastern regions. This spatial pattern of WUE anomalies was similar both in SRES A2 scenario and SRES B1 scenario indicating that the predicted results showed a strong negative effect on WUE even under a moderate climate with increasing warming and precipitation. Nevertheless, under the SRES A2 scenario with warmer and wetter future trend, the climate change scenario gives a more severe positive or negative effect on WUE than that of under SRES B1 scenario. Under the SRES A2 scenario, WUE would decrease slightly with 


\section{0s}

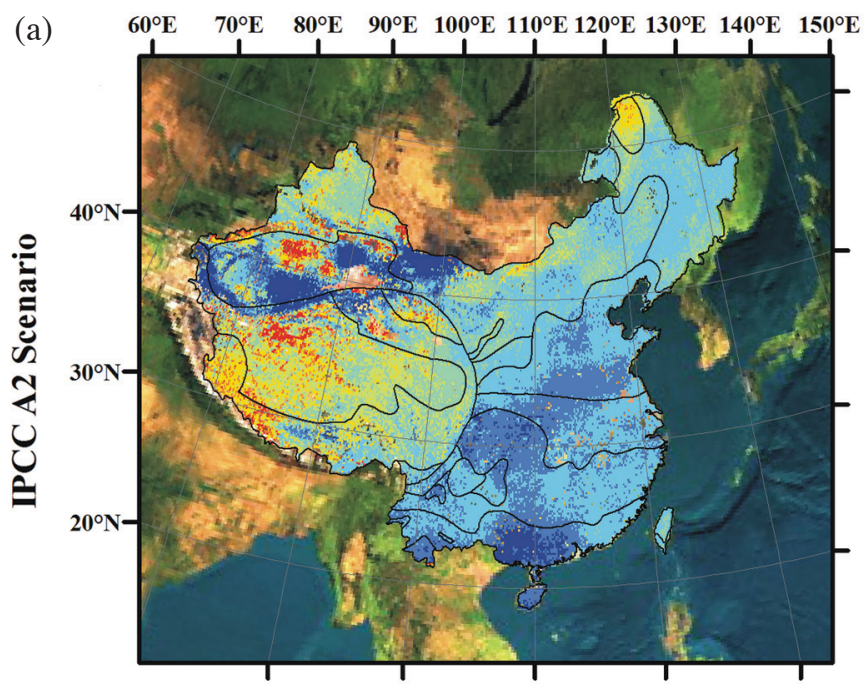

(c)
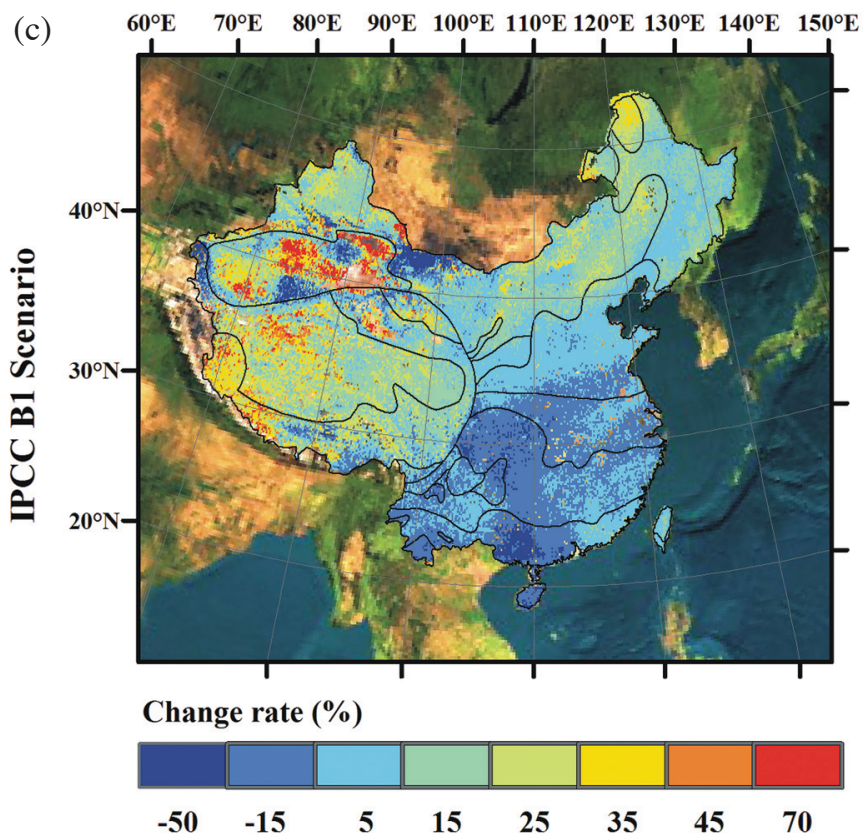

2090s

(b) $\quad 6^{\circ} \mathrm{E} \quad 7^{\circ} \mathrm{E} \quad 8^{\circ} \mathrm{E} \quad 9^{\circ} \mathrm{E} \quad 100^{\circ} \mathrm{E} \quad 110^{\circ} \mathrm{E} \quad 120^{\circ} \mathrm{E} \quad 130^{\circ} \mathrm{E} \quad 140^{\circ} \mathrm{E} \quad 150^{\circ} \mathrm{E}$

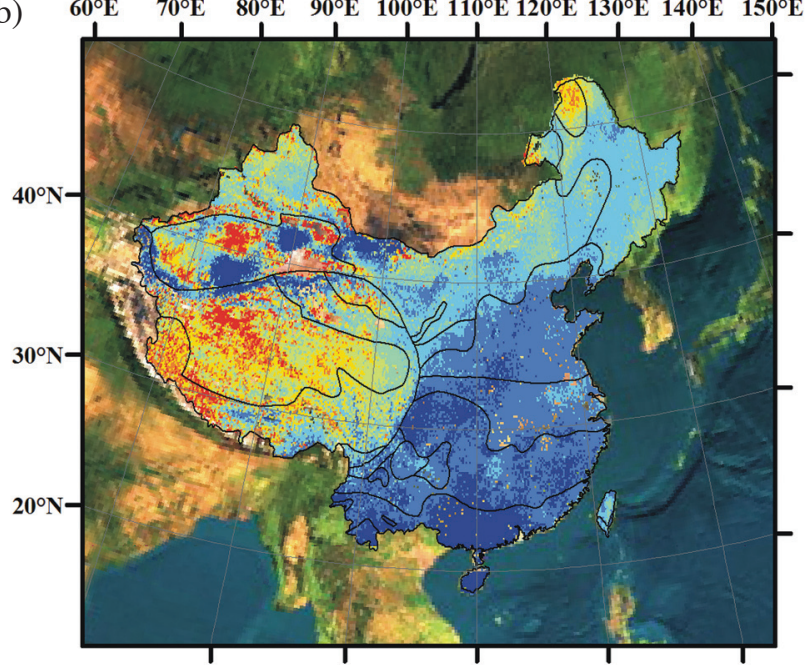

(d)

d) $\quad 60^{\circ} \mathrm{E} \quad 70^{\circ} \mathrm{E} \quad 80^{\circ} \mathrm{E} \quad 90^{\circ} \mathrm{E} \quad 100^{\circ} \mathrm{E} 110^{\circ} \mathrm{E} 120^{\circ} \mathrm{E} 130^{\circ} \mathrm{E} \quad 140^{\circ} \mathrm{E} \quad 150^{\circ} \mathrm{E}$

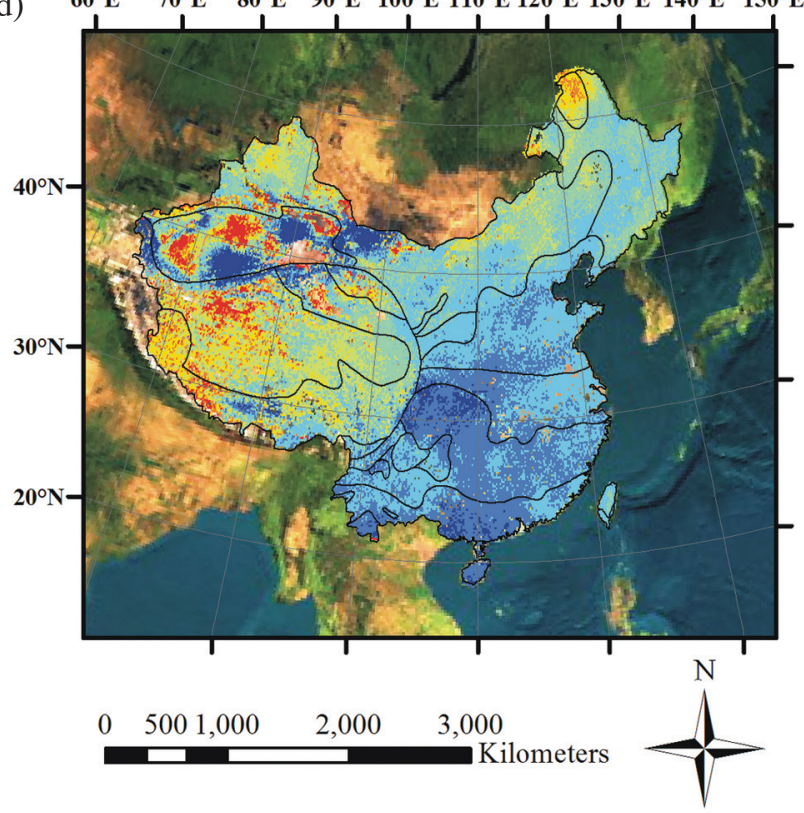

Fig. 5. WUE anomalies in the 2050s and 2090s (relative to the 2000s) in China under future IPCC scenarios.

a 5\% value in most areas of southeastern and northwestern China during the 2050s, and then WUE would decrease by approximately $15 \%$ in southeastern China during the 2090s. For the period of the 2050s under the SRES B1 scenario, the change rate of WUE would be similar to that of the SRES A2 scenario, but the WUE would decrease in a smaller area in southeastern China than that under the SRES A2 scenario. WUE of desert and tundra would change significantly with about a $45 \%$ increase under both climate change conditions indicating that the WUE in semi-arid and arid ecosystems would increase dramatically by plentiful rainfall than during the present day.

\subsection{Different Responses of WUE Among Climate Zones}

Zonal statistics were applied to calculate the mean WUE for each climate zone. The variations of WUE and its responses to heterogeneous $\mathrm{CO}_{2}$ enrichment for each climate zone are shown in Fig. 6. Under historical and future IPCC scenarios (A2, B1), the different time series patterns of WUE were present during the period from 1951 to 2099. WUE kept increasing in WMT, CT, PT and PF which is in contrast to the declining trends of WUE in MT, SS and MS. In addition, in WWT and DWT, WUE remained stable through the period 1951 - 2099, albeit of a different mag- 

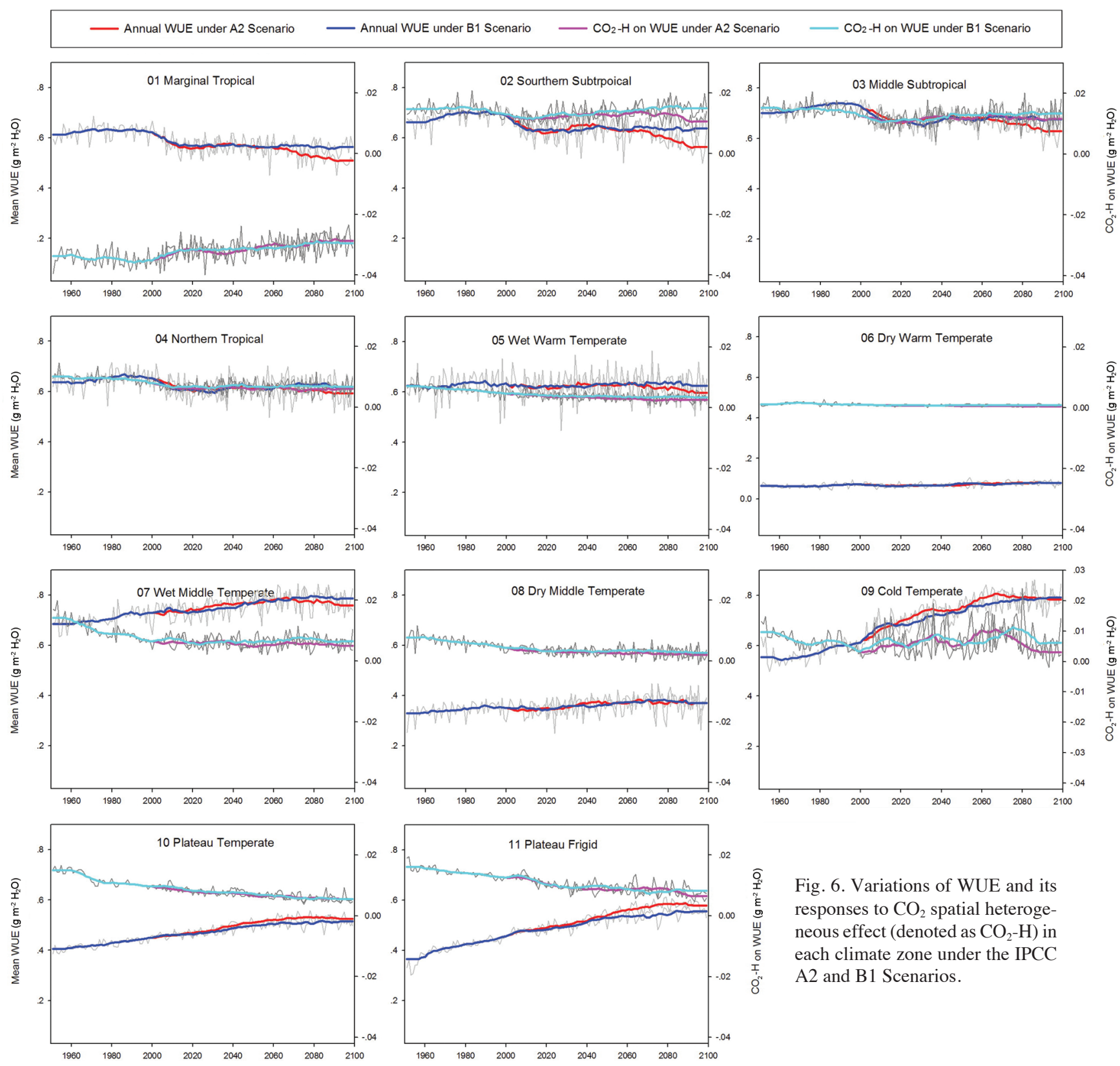

Fig. 6. Variations of WUE and its responses to $\mathrm{CO}_{2}$ spatial heterogeneous effect (denoted as $\mathrm{CO}_{2}-\mathrm{H}$ ) in each climate zone under the IPCC $\mathrm{A} 2$ and B1 Scenarios.

nitude. The increasing rate of WUE in CT was higher than the other climate zones with about a $0.2 \mathrm{~g} \mathrm{C} \mathrm{kg}^{-1} \mathrm{H}_{2} \mathrm{O}$ increment. In addition, the major vegetation cover of the Cold Temperate zone was boreal evergreen forest which was distinguished from other climate zones indicating that WUE in high latitude regions will increase significantly at the end of this century because huge boreal forests cover these high latitude regions. The WUE in MT and SS decreased during $2000-2100$ s, with a value of $0.6 \mathrm{~g} \mathrm{C} \mathrm{kg}^{-1} \mathrm{H}_{2} \mathrm{O}$. In WWT and DWT, the WUE remained constant due to the coupled effect both from climate change and rising $\mathrm{CO}_{2}$ concentration which led to a negative and positive effect respectively.

During the period 1951 - 2099, substantial variations existed in heterogeneous $\mathrm{CO}_{2}$ enrichment effects on WUE across each climate zone. Among all climate zones in China, SS and MS showed the highest response of WUE to $\mathrm{CO}_{2}$ spatial-temporal heterogeneity. For SS and MS, the WUE responses to heterogeneous $\mathrm{CO}_{2}$ (denoted as $\mathrm{CO}_{2}-\mathrm{H}$ ) were higher than $0.01 \mathrm{~g} \mathrm{C} \mathrm{kg}^{-1} \mathrm{H}_{2} \mathrm{O}$. Conversely, for MT zone, $\mathrm{CO}_{2}-\mathrm{H}$ on WUE showed negative effect with a value about $0.02 \mathrm{~g} \mathrm{C} \mathrm{kg}^{-1} \mathrm{H}_{2} \mathrm{O}$. WUE in $\mathrm{CT}$ was more sensitive to $\mathrm{CO}_{2}$ heterogeneity, with a magnitude of $0.01 \mathrm{~g} \mathrm{C} \mathrm{kg}^{-1} \mathrm{H}_{2} \mathrm{O}$. For most climate zones, the $\mathrm{CO}_{2}-\mathrm{H}$ with the highest value occurring in recent decades decreased during 1951 - 2099 which was in contrast to the increasing trends of atmospheric $\mathrm{CO}_{2}$ supposed by future IPCC scenarios. 
Compared with the simulation under IPCC A2 and B1 $\mathrm{CO}_{2}$ concentration scenarios with climate change, significant differences were shown both in WUE and $\mathrm{CO}_{2}-\mathrm{H}$. The time series patterns of annual WUE under A2 and B1 scenarios in each climate zone were different. In some climate zones at lower latitudes, such as MT, SS, MS, NT, WWT, WMT, the WUE under B1 scenarios were higher than that of A2 scenarios. However, in high latitude and plateau areas such as CT, PT, PF, the variations of WUE showed converse results during $21^{\text {st }}$ century. This implied that the major controlling factor of climate change on WUE in each climate zone would be altered by geographical and terrestrial ecosystems. For aspects concerning $\mathrm{CO}_{2}$ enrichment effects $\left(\mathrm{CO}_{2}-\mathrm{H}\right)$, the overall trends in most climate zones were present as our model simulation indicated that due to rising atmospheric $\mathrm{CO}_{2}$ concentration WUE under the $\mathrm{B} 1$ scenario in most climate zones (except for MT, $\mathrm{CT}$ and $\mathrm{PF}$ ) were substantially higher than under the A2 scenario. In Fig. 6, the positive effect of rising $\mathrm{CO}_{2}$ concentration would reach a maximum in the 2040s and then decrease in A2 scenario, while the positive effect would be effectively sustained until the end of $21^{\text {st }}$ century in the B1 scenario implying that the $\mathrm{CO}_{2}$ enhancement on WUE is limited.

\section{DISCUSSION}

\subsection{The Effect of Rising Atmospheric $\mathrm{CO}_{2}$ on WUE}

The IBIS simulation driven by IPCC future climate data and spatial-temporal variability of atmospheric $\mathrm{CO}_{2}$ show that spatial patterns of WUE are in similar agreement with other study results (Zhu et al. 2011). For quantity comparison, the simulated mean annual WUE was calculated for the period from 1990 to 2000 for major biomes using corresponding calculation equations. As the results indicate, different water use efficiencies have been found among different plant species. Large areas of cropland were classified as Savanna because the cropland was not represented in IBIS plant function types, Therefore, the WUE of Savanna is somewhat higher than that of a boreal forest because of higher productivity in cropland (Deng et al. 2006). The order of WUE in our study is similar to Tian's simulation results in the Southern United States (Tian et al. 2010). WUE is affected both by NPP and ET such that the changing patterns of WUE among different vegetation types are different from those of NPP and ET. According to different ecosystem characteristics in each plant function type (e.g., photosynthesis, water uptake ability), some vegetation types are more sensitive to environmental changes. Generally, grassland is more significantly affected by multiple climate change factors. In contrast, a forest has a better tolerance to water stress (Fig. 7a).

Increases in atmospheric $\mathrm{CO}_{2}$ concentrations promote increases in simulated WUE through the $\mathrm{CO}_{2}$ fertilization effect (Zhu et al. 2011) as well as observed results through tree-ring analysis (Andreu-Hayles et al. 2011). From the simulation experiments it has been shown that the spatialtemporal variations of atmospheric $\mathrm{CO}_{2}$ influence the assessment on WUE for each climate zone (Fig. 7b). The heterogeneous $\mathrm{CO}_{2}$ have positive effect on WUE for most climate zones, because the monthly averaged $\mathrm{CO}_{2}$ concentration in China is higher than the global average from the ESRL. The negative response in the MT zone could be probably explained by the relatively low $\mathrm{CO}_{2}$ concentration in growing seasons. Meanwhile, the enhancement effect was controlled by nitrogen and water availability whereby the difference between precipitation and potential evaportranspiration explaining part of variability. The underlying mechanisms of WUE response to spatial variations of atmospheric $\mathrm{CO}_{2}$ effect need to be further studied.

\subsection{Limitation and Implications for Future Ecohydro- logical Processes}

Most of the study results on WUE, including the model estimation, eddy-covariance calculation, and field investigation, vary widely in different spatial scale and geographical conditions (Bell et al. 2010). This diversity in estimation of WUE leads to a difficulty in reflecting WUE accurately for each ecosystem. Only in the same scale and calculation equation, the accuracy of WUE could be evaluated. Nevertheless, the variations of WUE as an assessing indicator of the coupling of ecological and hydrological processes are useful, albeit of uncertain value. Zhu et al. (2011) pointed out that major uncertainties in WUE were caused by the spatial scale and geographical differences, while Tian et al. (2010) suggested that uncertainties might come from model parameters and structures which simplify some ecosystemprocesses. This study did not include a cropland ecosystem into the simulations(instead of the savanna ecosystem). This simplification might result in an overestimation of WUE for a savanna because of a higher vegetation cover fraction in cropland which would affect modeled NPP.

Our analysis of the mechanisms controlling WUE in China in future IPCC scenarios has a number of policy implications (Fig. 8). Three obvious phenomenon that change the pattern of WUE in China and will have some effect on the carbon and water cycle of a terrestrial ecosystem such that (1) WUE will decrease in most areas of southern and eastern China; (2) WUE will increase in Tibet Plateau and some semi-arid areas of western China; and, (3) the decreasing rate of WUE will enhance at the end of $21^{\text {st }}$ century under uncontrolled anthropogenic emission scenarios (A2). These phenomenon were partly observed by long-term observations (Hu et al. 2010). This analysis indicates that our terrestrial ecosystems will lose potential carbon uptake due to ever more extreme drought or flood as recent studies report (Alo et al. 2008b); crops will need more water to sustain a constant yield. 
Rising atmospheric $\mathrm{CO}_{2}$ concentrations, as an indicator of climate change, is one of the most pressing environmental concerns in China (Reich 2010). Our simulations, consistent with some experiments, have shown that the spatial-temporal variation of $\mathrm{CO}_{2}$ will affect plant photosynthesis and water cycles. Therefore, rising $\mathrm{CO}_{2}$ concentration will partly help to mitigate effect of climate change although our analysis suggests that the benefits of these WUE increment might be limited. In fact, a partial correlation analysis between WUE and the spatial-temporal variations of atmospheric $\mathrm{CO}_{2}$ concentrations show that the variations of WUE are associated with $\mathrm{CO}_{2}$ concentration in 80 to $90 \%$ of the area of boreal forest ecosystems (Fig. 8c). It can be inferred that The WUE in boreal forests where large high latitude covered areas of earth will increase due to the $\mathrm{CO}_{2}$ emission continuously increases. As the IPCC future scenarios predict, the annual precipitation in high latitude of Northern Hemisphere will increase (Doherty et al. 2010). In addition, the increasing trend of WUE was found in higher latitude regions, where in contrast to that in lower latitude regions. Recent studies reported that the higher WUE can increase the drought stress experienced by plants by regulating stomatal responses (Cruz et al. 2010; Pingintha et al. 2010), even through the worsened drought and rising temperature tend to offset this positive effect (Brienen et al. 2011). This might imply that the ecosystems in middle and low latitude areas have a weakened effect on resisting an extreme climate event such as drought, while the boreal forest has an enhanced effect on
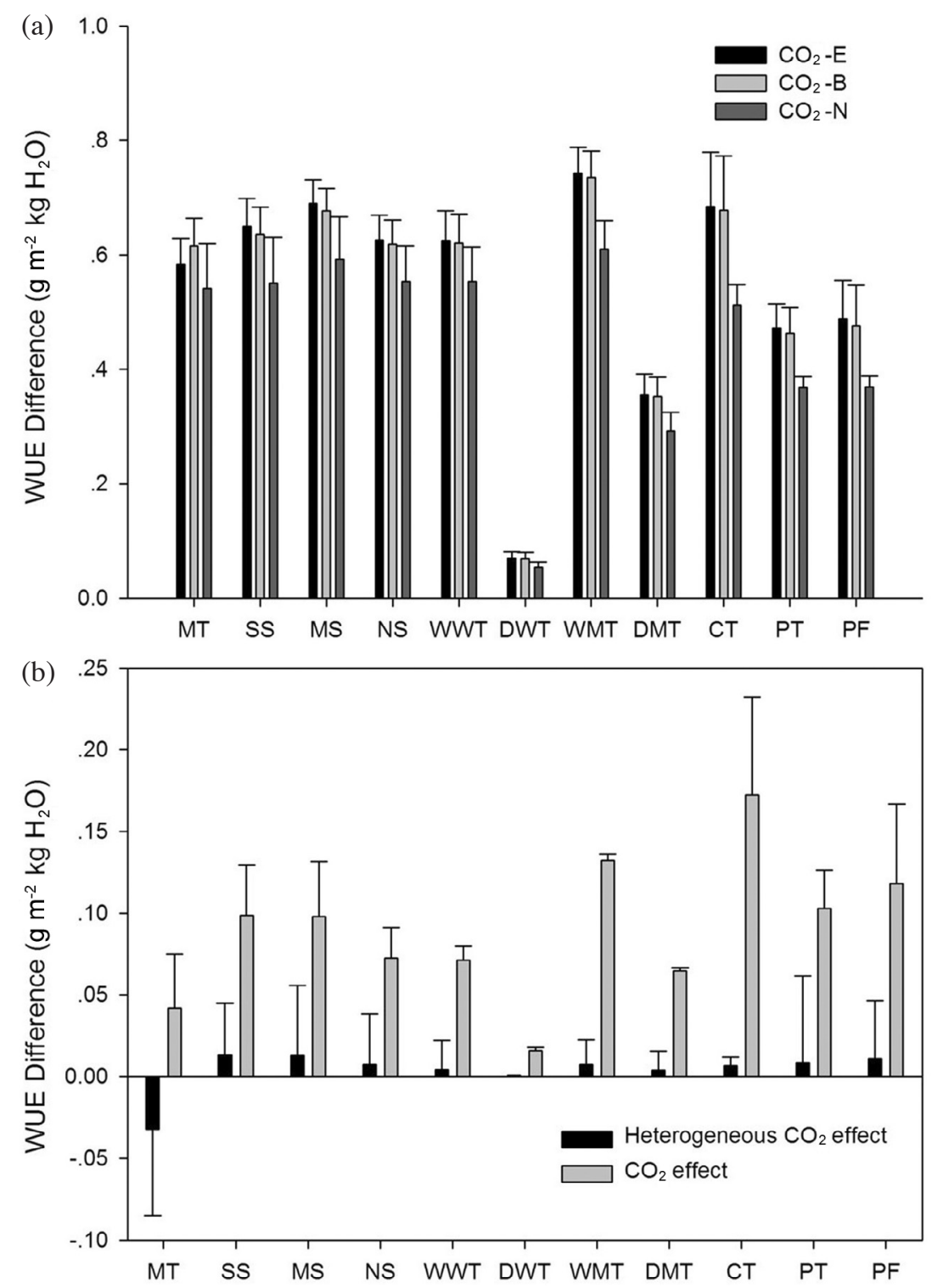

Fig. 7. The averaged WUE of different simulation experiments over the period of $1951-2099$ and its standard deviation. $\mathrm{CO}_{2}-\mathrm{E}$ simulation represents heterogeneous $\mathrm{CO}_{2}$ condition; $\mathrm{CO}_{2}-\mathrm{B}$ simulation represents the spatial-uniform $\mathrm{CO}_{2}$ condition; $\mathrm{CO}_{2}-\mathrm{N}$ simulation represents no $\mathrm{CO}_{2}$ increase condition. 
(a)

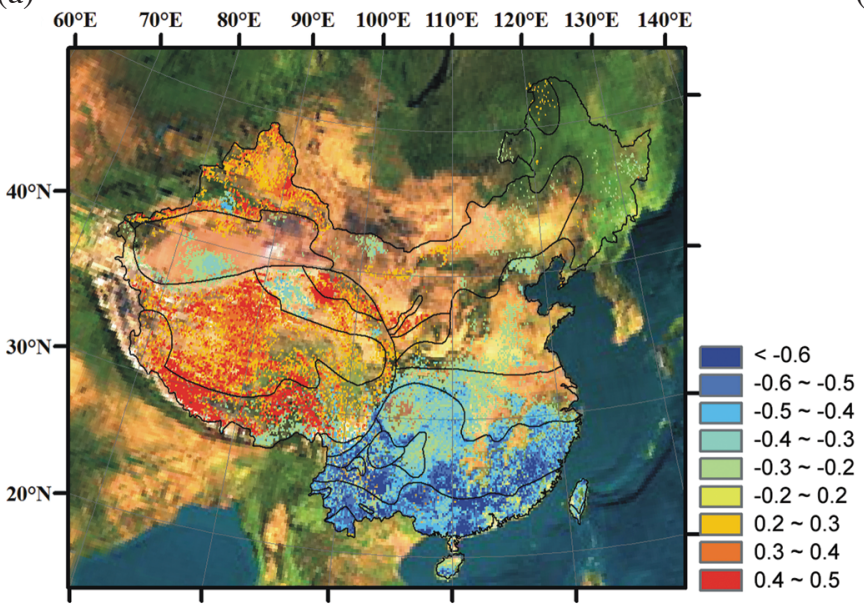

(c)

Partial correlation WUE and temperature

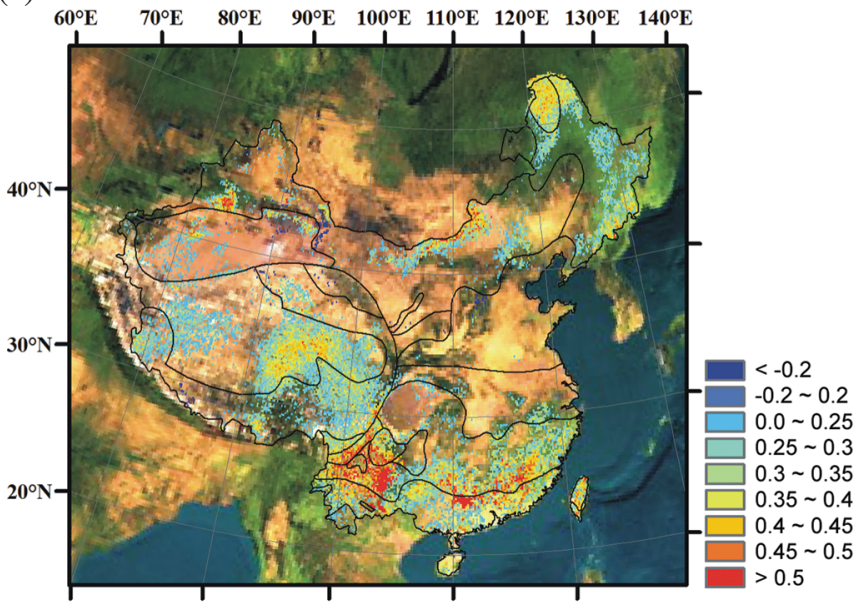

Partial correlation WUE and $\mathrm{CO}_{2}$ concentration

tolerating drought events. As recent increases in the intensity of heavy precipitation and drought events over a large part of the Chinese mainland (Gemmer et al. 2011; Min et al. 2011), it is important to evaluate the variations of WUE and its response to land surface ecosystems.

\section{CONCLUSIONS}

This study represents a first attempt to assess the future changes of WUE with the goal of understanding the interactions between carbon and water resources under climate change and spatial heterogeneity of atmospheric $\mathrm{CO}_{2}$ in China. Our results show that the averaged WUE in A2 and B1 scenarios have increased over 2010 - 2060 and 2010 - 2080, respectively, and then decreased into 2090s with substantial inter-annual variation. This implies that the enhancement of rising $\mathrm{CO}_{2}$ concentration on WUE was limited. The spatial heterogeneity of atmospheric $\mathrm{CO}_{2}$ has a considerable effect on WUE climate zones compared to uniform $\mathrm{CO}_{2}$ patterns. Various WUE climate zones were different and showed dif- (b)

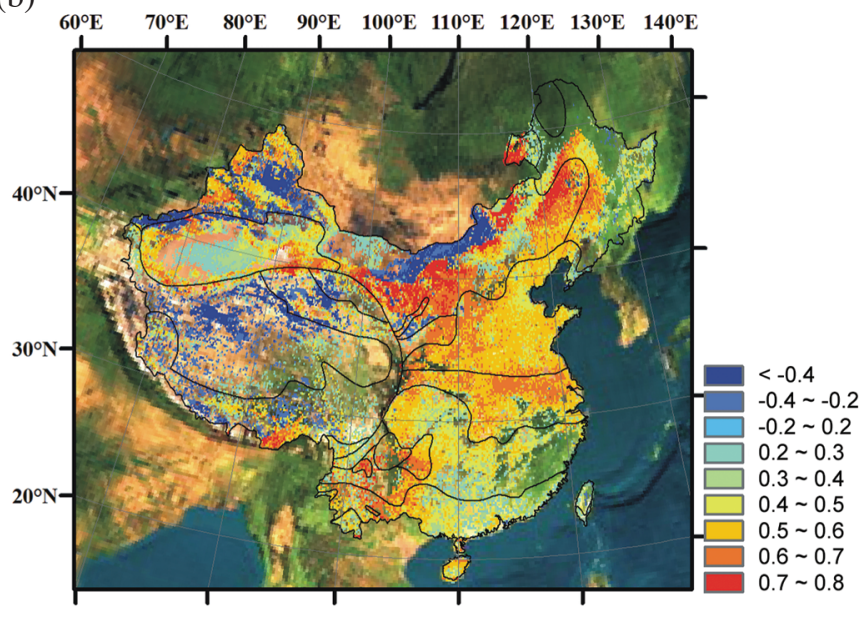

Partial correlation WUE and preciptation

Fig. 8. Partial correlation in the spatial domain between WUE and temperature, precipitation, or $\mathrm{CO}_{2}$ concentration. Significant correlations are shown $(\mathrm{p}<0.01)$ wherein the correlation coefficient is higher/lower than \pm 0.2 . ferent responses to spatial-temporal patterns of atmospheric $\mathrm{CO}_{2}$. The contributions of atmospheric $\mathrm{CO}_{2}$ to WUE need to be further identified in future studies.

Acknowledgements Funding support partially from The NSF China Major Program (61190114 and 41171324), The State Key Fundamental Science Funds of China (2011CB302705, 2010CB950702, and 2010CB428503), The Funds for Ph.D. Education (20110091110028), The State High Technology Funds of China (2009AA122001 and 2009AA122005), The State Key Basic Research Funds of China (2007FY110300-04 and 2007FY110300-08), The Project Funded by the Priority Academic Program Development of Jiangsu Higher Education Institutions, Zhejiang province key science and technology innovation team (2010R50030). We are grateful to the SCIAMACHY teams for the availability of SCIAMACHY WFM-DOAS data and thank the anonymous reviewers for their helpful contribution to this study. Any use of trade, product, or firm names is for descriptive purposes only and does not imply endorsement by the US Government. 


\section{REFERENCES}

Alo, C. A. and G. Wang, 2008a: Hydrological impact of the potential future vegetation response to climate changes projected by 8 GCMs. J. Geophys. Res., 113, G03011, doi: 10.1029/2007jg000598. [Link]

Alo, C. A. and G. Wang, 2008b: Potential future changes of the terrestrial ecosystem based on climate projections by eight general circulation models. J. Geophys. Res., 113, G01004, doi: 10.1029/2007jg000528. [Link]

Andreu-Hayles, L., O. Planells, E. Gutiérrez, E. Muntan, G. Helle, K. J. Anchukaitis, and G. H. Schleser, 2011: Long tree-ring chronologies reveal $20^{\text {th }}$ century increases in water-use efficiency but no enhancement of tree growth at five Iberian pine forests. Global Change Biol., 17, 2095-2112, doi: 10.1111/j.1365-2486.2010. 02373.x. [Link]

Arneth, A., S. P. Harrison, S. Zaehle, K. Tsigaridis, S. Menon, P. J. Bartlein, J. Feichter, A. Korhola, M. Kulmala, D. O’Donnell, G. Schurgers, S. Sorvari, and T. Vesala, 2010: Terrestrial biogeochemical feedbacks in the climate system. Nat. Geosci., 3, 525-532, doi: 10. 1038/ngeo905. [Link]

Baldocchi, D., 1994: A comparative study of mass and energy exchange rates over a closed $\mathrm{C}_{3}$ (wheat) and an open $\mathrm{C}_{4}$ (corn) crop: II. $\mathrm{CO}_{2}$ exchange and water use efficiency. Agric. For. Meteorol., 67, 291-321, doi: 10.10 16/0168-1923(94)90008-6. [Link]

Baldocchi, D., 1997: Measuring and modelling carbon dioxide and water vapour exchange over a temperate broadleaved forest during the 1995 summer drought. Plant Cell Environ., 20, 1108-1122, doi: 10.1046/j.1365-30 40.1997.d01-147.x. [Link]

Bell, J. E., E. Weng, and Y. Luo, 2010: Ecohydrological responses to multifactor global change in a tallgrass prairie: A modeling analysis. J. Geophys. Res., 115, G04042, doi: 10.1029/2009jg001120. [Link]

Brienen, R. J. W., W. Wanek, and P. Hietz, 2011: Stable carbon isotopes in tree rings indicate improved water use efficiency and drought responses of a tropical dry forest tree species. Trees, 25, 103-113, doi: 10.1007/ s00468-010-0474-1. [Link]

Buchwitz, M., O. Schneising, J. P. Burrows, H. Bovensmann, and J. Notholt, 2007: First direct observation of the atmospheric $\mathrm{CO}_{2}$ year-to-year increase from space. Atmos. Chem. Phys. Discuss., 7, 6719-6735, doi: 10. 5194/acpd-7-6719-2007. [Link]

Campbell, G. S. and J. M. Norman, 1998: An Introduction to Environmental Biophysics, Springer-Verlag, $2^{\text {nd }}$ edition, New York, 41-53.

Chapin, F. S., P. A. Matson, and H. A. Mooney, 2002: Principles of Terrestrial Ecosystem Ecology, Springer Verlag, New York.

Ciais, P., P. Peylin, and P. Bousquet, 2000: Regional bio- spheric carbon fluxes as inferred from atmospheric $\mathrm{CO}_{2}$ measurements. Ecol. Appl., 10, 1574-1589, doi: 10.1890/1051-0761(2000)010[1574:RBCFAI]2.0.CO; 2. [Link]

Cramer, W., A. Bondeau, F. I. Woodward, I. C. Prentice, R. A. Betts, V. Brovkin, P. M. Cox, V. Fisher, J. A. Foley, A. D. Friend, C. Kucharik, M. R. Lomas, N. Ramankutty, S. Sitch, B. Smith, A. White, and C. YoungMolling, 2001: Global response of terrestrial ecosystem structure and function to $\mathrm{CO}_{2}$ and climate change: results from six dynamic global vegetation models. Global Change Biol., 7, 357-373, doi: 10.1046/j.13652486.2001.00383.x. [Link]

Cruz, F. T., A. J. Pitman, and Y. P. Wang, 2010: Can the stomatal response to higher atmospheric carbon dioxide explain the unusual temperatures during the 2002 Murray-Darling Basin drought? J. Geophys. Res., 115, D02101, doi 10.1029/2009jd012767. [Link]

Deng, X. P., L. Shan, H. Zhang, and N. C. Turner, 2006: Improving agricultural water use efficiency in arid and semiarid areas of China. Agric. Water Manage., 80, 23-40, doi: 10.1016/j.agwat.2005.07.021. [Link]

Doherty, R. M., S. Sitch, B. Smith, S. L. Lewis, and P. K. Thornton, 2010: Implications of future climate and atmospheric $\mathrm{CO}_{2}$ content for regional biogeochemistry, biogeography and ecosystem services across East Africa. Global Change Biol., 16, 617-640, doi: 10.1111/ j.1365-2486.2009.01997.x. [Link]

Erbs, M., J. Franzaring, P. Högy, and A. Fangmeier, 2009: Free-air $\mathrm{CO}_{2}$ enrichment in a wheat-weed assembly Effects on water relations. Basic Appl. Ecol., 10, 358367, doi: 10.1016/j.baae.2008.08.008. [Link]

Farquhar, G. D. and T. D. Sharkey, 1982: Stomatal conductance and photosynthesis. Ann. Rev. Plant Phys., 33, 317-345, doi: 10.1146/annurev.pp.33.060182.001533. [Link]

Farquhar, G. D., S. von Caemmerer, and J. A. Berry, 1980: A biochemical model of photosynthetic $\mathrm{CO}_{2}$ assimilation in leaves of $\mathrm{C}_{3}$ species. Planta, 149, 78-90, doi: 10.1007/BF00386231. [Link]

Foley, J. A., I. C. Prentice, N. Ramankutty, S. Levis, D. Pollard, S. Sitch, and A. Haxeltine, 1996: An integrated biosphere model of land surface processes, terrestrial carbon balance, and vegetation dynamics. Global Biogeochem. Cycles, 10, 603-628, doi: 10.1029/96GB02 692. [Link]

Friedlingstein, P., R. A. Houghton, G. Marland, J. Hackler, T. A. Boden, T. J. Conway, J. G. Canadell, M. R. Raupach, P. Ciais, and C. Le Quéré, 2010: Update on $\mathrm{CO}_{2}$ emissions. Nat. Geosci., 3, 811-812, doi: 10.1038/ ngeo1022. [Link]

Gemmer, M., T. Fischer, T. Jiang, B. Su, and L. L. Liu, 2011: Trends in precipitation extremes in the Zhujiang River basin, South China. J. Climate, 24, 750-761, doi: 


\subsection{5/2010JCLI3717.1. [Link]}

Geng, S., F. W. T. Penning de Vries, and I. Supit, 1986: A simple method for generating daily rainfall data. $A g$ ric. For. Meteorol., 36, 363-376, doi: 10.1016/01681923(86)90014-6. [Link]

Gibbs, H., L. Olsen, and T. Boden, 2006: Major World Ecosystem Complexes Ranked by Carbon in Live Vegetation: An Updated Database Using the GLC2000 Land Cover Product. Oak Ridge National Laboratory, Oak Ridge, USA.

Hu, Z., G. Yu, Y. Fu, X. Sun, Y. Li, P. Shi, Y. Wang, and Z. Zheng, 2008: Effects of vegetation control on ecosystem water use efficiency within and among four grassland ecosystems in China. Global Change Biol., 14, 1609-1619, doi: 10.1111/j.1365-2486.2008.01582.x. [Link]

Hu, Z., G. Yu, J. Fan, H. Zhong, S. Wang, and S. Li, 2010: Precipitation-use efficiency along a 4500-km grassland transect. Glob. Ecol. Biogeogr., 19, 842-851, doi: 10.1111/j.1466-8238.2010.00564.x. [Link]

Hutchinson, M. F., 1984: A summary of some surface fitting and contouring programs for noisy data. CSIRO Division of Mathematics and Statistics, Consulting Report ACT 84/6, Canberra, Australia.

Hutchinson, M. F. and P. E. Gessler, 1994: Splines - More than just a smooth interpolator. Geoderma, 62, 45-67, doi: 10.1016/0016-7061(94)90027-2. [Link]

Huxman , T. E., M. D. Smith, P. A. Fay, A. K. Knapp, M. R. Shaw, M. E. Loik, S. D. Smith, D. T. Tissue, J. C. Zak, J. F. Weltzin, W. T. Pockman, O. E. Sala, B. M. Haddad, J. Harte, G. W. Koch, S. Schwinning, E. E. Small, and D. G. Williams, 2004: Convergence across biomes to a common rain-use efficiency. Nature, $\mathbf{4 2 9}$, 651-654, doi: 10.1038/nature02561. [Link]

IPCC, 2001: Climate Change 2001: The Scientific Basis. Contribution of Working Group I to the Third Assessment Report of the Intergovernmental Panel on Climate Change, Cambridge, United Kingdom and New York, NY, USA.

IPCC, 2007: Climate Change 2007: The Physical Science Basis. Contribution of Working Group I to the Fourth Assessment Report of the Intergovernmental Panel on Climate Change, Cambridge, United Kingdom and New York, NY, USA.

Kucharik, C. J., J. A. Foley, C. Delire, V. A. Fisher, M. T. Coe, J. D. Lenters, C. Young-Molling, N. Ramankutty, J. M. Norman, and S. T. Gower, 2000: Testing the performance of a Dynamic Global Ecosystem Model: Water balance, carbon balance, and vegetation structure. Global Biogeochem. Cycles, 14, 795-825, doi: 10. 1029/1999GB001138. [Link]

Kuglitsch, F. G., M. Reichstein, C. Beer, A. Carrara, R. Ceulemans, A. Granier, I. A. Janssens, B. Koestner, A. Lindroth, D. Loustau, G. Matteucci, L. Montagnani,
E. J. Moors, D. Papale, K. Pilegaard, S. Rambal, C. Rebmann, E. D. Schulze, G. Seufert, H. Verbeeck, T. Vesala, M. Aubinet, C. Bernhofer, T. Foken, T. Grunwald, B. Heinesch, W. Kutsch, T. Laurila, B. Longdoz, F. Miglietta, M. J. Sanz, and R. Valentini, 2008: Characterisation of ecosystem water-use efficiency of European forests from eddy covariance measurements. Biogeosci. Discuss., 5, 4481-4519, doi: 10.5194/bgd5-4481-2008. [Link]

Law, B. E., E. Falge, L. Gu, D. D. Baldocchi, P. Bakwin, P. Berbigier, K. Davis, A. J. Dolman, M. Falk, J. D. Fuentes, A. Goldstein, A. Granier, A. Grelle, D. Hollinger, I. A. Janssens, P. Jarvis, N. O. Jensen, G. Katul, Y. Mahli, G. Matteucci, T. Meyers, R. Monson, W. Munger, W. Oechel, R. Olson, K. Pilegaard, K. T. Paw U, H. Thorgeirsson, R. Valentini, S. Verma, T. Vesala, K. Wilson, and S. Wofsy, 2002: Environmental controls over carbon dioxide and water vapor exchange of terrestrial vegetation. Agric. For. Meteorol., 113, 97120, doi: 10.1016/S0168-1923(02)00104-1. [Link]

LeHouerou, H. N., 1984: Rain use efficiency: A unifying concept in arid-land ecology. J. Arid. Environ., 7, 213247.

Liu, J., D. T. Price, and J. M. Chen, 2005: Nitrogen controls on ecosystem carbon sequestration: a model implementation and application to Saskatchewan, Canada. Ecol. Model., 186, 178-195, doi: 10.1016/j.ecolmodel.2005. 01.036. [Link]

Min, S. K., X. Zhang, F. W.Zwiers, and G. C. Hegerl, 2011: Human contribution to more-intense precipitation extremes. Nature, 470, 378-381, doi: 10.1038/nature097 63. [Link]

Peñuelas, J., J. G. Canadell, and R. Ogaya, 2010: Increased water-use efficiency during the 20th century did not translate into enhanced tree growth. Glob. Ecol. Biogeogr., 20,597-608, doi: 10.1111/j.1466-8238.2010.00 608.x. [Link]

Peters, W., A. R. Jacobson, C. Sweeney, A. E. Andrews, T. J. Conway, K. Masarie, J. B. Miller, L. M. P. Bruhwiler, G. Pétron, A. I. Hirsch, D. E. J. Worthy, G. R. van der Werf, J. T. Randerson, P. O. Wennberg, M. C. Krol, and P. P. Tans, 2007: An atmospheric perspective on North American carbon dioxide exchange: CarbonTracker. PNAS, 104, 18925-18930, doi: 10.1073/ pnas.0708986104. [Link]

Pingintha, N., M. Y. Leclerc, J. P. Beasley, D. Durden, G. Zhang, C. Senthong, and D. Rowland, 2010: Hysteresis response of daytime net ecosystem exchange during drought. Biogeosciences, 7, 1159-1170, doi: 10.5194/ bg-7-1159-2010. [Link]

Reich, P. B., 2010: The carbon dioxide exchange. Science, 329, 774-775, doi: 10.1126/science.1194353. [Link]

Richards, R. A., G. J. Rebetzke, A. G. Condon, and A. F. van Herwaarden, 2002: Breeding opportunities for increas- 
ing the efficiency of water use and crop yield in temperate cereals. Crop Sci., 42, 111-121, doi: 10.2135/ cropsci2002.0111. [Link]

Richardson, C. W., 1981: Stochastic simulation of daily precipitation, temperature, and solar radiation. Water Resour.Res., 17, 182-190, doi: 10.1029/WR017i001p0 0182. [Link]

Richardson, C. W. and D. A. Wright, 1984: WGEN: A Model for Generating Daily Weather Variables. US Department of Agriculture, Agricultural Research Service, ARS-8, 83 pp.

Steduto, P. and R. Albrizio, 2005: Resource use efficiency of field-grown sunflower, sorghum, wheat and chickpea: II. Water use efficiency and comparison with radiation use efficiency. Agric. For. Meteorol., 130, 269281, doi: 10.1016/j.agrformet.2005.04.003. [Link]

Task, G., 2000: Global gridded surfaces of selected soil characteristics (IGBP-DIS). International GeosphereBiosphere Programme-Data and Information Services, Oak Ridge National Laboratory Distributed Active Archive Center, Oak Ridge, Tennessee, USA, available at http://www.daac.ornl.gov/.

Thompson, S. L. and D. Pollard, 1995a: A global climate model (GENESIS) with a land-surface transfer scheme (LSX). Part I: Present climate simulation. J. Climate, 8, 732-761, doi: 10.1175/1520-0442(1995)008<0732: AGCMWA $>2.0 . C O ; 2$. [Link]

Thompson, S. L. and D. Pollard, 1995b: A global climate model (GENESIS) with a land-surface transfer scheme (LSX). Part II: $\mathrm{CO}_{2}$ Sensitivity. J. Climate, 8, 11041121, doi: 10.1175/1520-0442(1995)008<1104:AGCMWA $>2.0 . C O ; 2$. [Link]

Tian, H., G. Chen, M. Liu, C. Zhang, G. Sun, C. Lu, X. Xu, W. Ren, S. Pan, and A. Chappelka, 2010: Model estimates of net primary productivity, evapotranspiration, and water use efficiency in the terrestrial ecosystems of the southern United States during 1895-2007. For. Ecol. Manage., 259, 1311-1327, doi: 10.1016/j. foreco.2009.10.009. [Link]

Twine, T. E. and C. J. Kucharik, 2008: Evaluating a terrestrial ecosystem model with satellite information of greenness. J. Geophys. Res., 113, G03027, doi: 10.1029/20 07jg000599. [Link]

Vano, J. A., J. A. Foley, C. J. Kucharik, and M. T. Coe, 2006: Evaluating the seasonal and interannual variations in water balance in northern Wisconsin using a land surface model. J. Geophys. Res., 111, G02025, doi: 10.10 29/2005jg000112. [Link]

Xu, L. K. and T. C. Hsiao, 2004: Predicted versus measured photosynthetic water-use efficiency of crop stands un- der dynamically changing field environments. J. Exp. Bot., 55, 2395-2411.

Yokota, T., Y. Yoshida, N. Eguchi, Y. Ota, T. Tanaka, H. Watanabe, and S. Maksyutov, 2009: Global concentrations of $\mathrm{CO}_{2}$ and $\mathrm{CH}_{4}$ retrieved from GOSAT: First preliminary results. SOLA, 5, 160-163, doi: 10.2151/ sola.2009-041. [Link]

Yu, G. R., Q. F. Wang, and J. Zhuang, 2004: Modeling the water use efficiency of soybean and maize plants under environmental stresses: Application of a synthetic model of photosynthesis-transpiration based on stomatal behavior. J. Plant Physiol., 161, 303-318, doi: 10.1078/0176-1617-00972. [Link]

Yu, G., X. Song, Q. Wang, Y. Liu, D. Guan, J. Yan, X. Sun, L. Zhang, and X. Wen, 2008: Water-use efficiency of forest ecosystems in eastern China and its relations to climatic variables. New Phytol., 177, 927-937, doi: 10.1111/j.1469-8137.2007.02316.x. [Link]

Zhang, D., J. Tang, G. Shi, T. Nakazawa, S. Aoki, S. Sugawara, M. Wen, S. Morimoto, P. K. Patra, T. Hayasaka, and T. Saeki, 2008: Temporal and spatial variations of the atmospheric $\mathrm{CO}_{2}$ concentration in China. Geophys. Res. Lett., 35, L03801, doi: 10.1029/2007GL032531. [Link]

Zhang, Z., H. Jiang, J. Liu, W. Ju, and X. Zhang, 2013a: Effect of heterogeneous atmospheric $\mathrm{CO}_{2}$ on simulated global carbon budget. Global Planet. Change, 101, 3351, doi: 10.1016/j.gloplacha.2012.12.002. [Link]

Zhang, Z., H. Jiang, J. Liu, G. Zhou, and S. Liu, 2013b: The spatial-temporal dynamics of atmospheric $\mathrm{CO}_{2}$ concentration and the carbon sequestration enhancement in the terrestrial ecosystems of China. Environ. Modell. Softw., under review.

Zheng, Y., Z. Xie, G. M. Rimmington, Y. Yu, Y. Gao, G. Zhou, P. An, X. Li, W. Tsuji, and H. Shimizu, 2010: Elevated $\mathrm{CO}_{2}$ accelerates net assimilation rate and enhance growth of dominant shrub species in a sand dune in central Inner Mongolia. Environ. Exp. Bot., 68, 3136, doi: 10.1016/j.envexpbot.2009.11.005. [Link]

Zhu, Q., H. Jiang, J. Liu, X. Wei, C. Peng, X. Fang, S. Liu, G. Zhou, S. Yu, and W. Ju, 2010: Evaluating the spatiotemporal variations of water budget across China over 1951-2006 using IBIS model. Hydrol. Process., 24, 429-445, doi: 10.1002/hyp.7496. [Link]

Zhu, Q., H. Jiang, C. Peng, J. Liu, X. Wei, X. Fang, S. Liu, G. Zhou, and S. Yu, 2011: Evaluating the effects of future climate change and elevated $\mathrm{CO}_{2}$ on the water use efficiency in terrestrial ecosystems of China. Ecol. Model., 222, 2414-2429, doi: 10.1016/j.ecolmodel.2010.09.035. [Link] 